\title{
Penggunaan Media Audiovisual pada Model Inkuiri Terbimbing terhadap Keterampilan Proses Sains dan Penguasaan Konsep IPA
}

\author{
Ainun Magfirah $^{1}$, Arif Hidayat ${ }^{2}$, Susriyati Mahanal ${ }^{3}$ \\ ${ }^{1}$ Pendidikan Dasar-Universitas Negeri Malang \\ ${ }^{2}$ Pendidikan Fisika-Universitas Negeri Malang \\ ${ }^{3}$ Pendidikan Biologi-Universitas Negeri Malang
}

\begin{tabular}{l} 
INFO ARTIKEL \\
\hline Riwayat Artikel: \\
Diterima: 06-12-2019 \\
Disetujui: $25-01-2019$ \\
\hline
\end{tabular}

Kata kunci:
audiovisual media;
guided inquiry;
science process skills;
mastery of concepts;
media audiovisual;
inkuiri terbimbing;
keterampilan proses sains;
penguasaan konsep

penguasaan konsep

\begin{abstract}
This research was aimed to know the use of audiovisual media in a guided inquiry model of science processskills and mastery of students' concepts in science subjects. The low level of science process skills and mastery of concepts that exist today, becomes the urgency of this research. in this study, the type of research used was quasi-experimental research using two learning classes as research samples with different treatments. The sample is divided into experimental class and control class with simple random sampling technique. The analysis showed that there were significant differences in the experimental class with media use audiovisual in the guided inquiry model with the average value of science process skills and mastery of concepts is higher than the control class.
\end{abstract}

ABSTRAK

\begin{abstract}
Abstrak: Penelitian ini bertujuan untuk mengetahui penggunaan media audiovisual pada model inkuiri terbimbing terhadap keterampilan proses sains dan penguasaan konsep siswa pada mata pelajaran IPA. Rendahnya keterampilan proses sains dan penguasaan konsep saat ini, menjadi urgensi penelitian ini. Jenis penelitian yang digunakan merupakan penelitian kuasi eksperimen dengan menggunakan dua kelas belajar sebagai sampel penelitian dengan perlakuan yang berbeda. Sampel tersebut dibedakan menjadi kelas eksperimen dan kelas kontrol dengan simple random sampling. Hasil kajian menghasilkan ada perbedaan yang signifikan pada kelas eksperimen dengan penggunaan media audiovisual pada model inkuiri terbimbing dengan nilai rata-rata Keterampilan Proses Sains dan penguasan konsep lebih tinggi dibandingkan kelas kontrol.
\end{abstract}

\author{
Alamat Korespondensi: \\ Ainun Magfirah \\ Pendidikan Dasar \\ Universitas Negeri Malang \\ Jalan Semarang 5 Malang \\ E-mail: firahyati@gmail.com
}

Pembelajaran IPA di sekolah dirancang dan dilaksanakan sebagai cara mencari tahu dengan tujuan agar siswa dapat memahami fenomena alam secara mendalam (Depdiknas, 2007). Pembelajaran IPA bukan hanya sekedar fakta atau konsep pengetahuan yang diterima oleh siswa, tetapi juga suatu proses untuk dilaksanakan. Dalam pembelajaran IPA di sekolah siswa diharapkan belajar secara langsung dengan cara alamiah agar keterampilan proses sains didapatkan siswa sehingga memudahkan siswa menguasai konsep materi. Keterampilan Proses Sains adalah keterampilan pemecahan masalah secara terstruktur dengan mengimplikasikan keterampilan berpikir siswa untuk membuat prediksi atau mengajukan pertanyaan, melakukan kegiatan mengumpulkan bukti untuk menjawab pertanyaan kemudian menyajikan hasil. Pembelajaran sains harus diarahkan agar siswa dapat menguasai proses sains yang melibatkan keterampilan proses sains dan produk sains melalui pembelajaran dengan pola kegiatan bertahap, memberikan pembelajaran sesuai dengan kenyataan dan mengajak siswa menemukan konsep melalui pengamatan (Supriyatman \& Sukarno, 2014).

Kenyataannya kurangnya kesadaran mengenai pembelajaran IPA yang menekankan pada proses ilmiah masih banyak ditemui pada penelitian-penelitian yang telah ada. Dalam proses pembelajaran yang ada kurang melibatkan siswa, siswa langsung menerima pengetahuan yang ditransfer guru sehingga siswa hanya belajar di ranah kognitif rendah dan tidak terbiasa mengembangkan potensi pemikirannya (Nugraha, Kaniawati, Rusdiana, \& Kirana, 2016). Selain itu, didapati juga masalah lain yaitu pembelajaran dilakukan hanya sebatas pemahaman transfer pengetahuan tanpa dilakukan kegiatan yang melibatkan proses alamiah yang mendorong siswa menemukan konsep sehingga menyebabkan siswa tidak mempunyai kesempatan untuk melakukan pengamatan dan eksperimen (Dewi, Dantes, \& Sadia, 2013). 
Pengembangan pembelajaran merupakan langkah yang dapat dilakukan guru sebagai alternatif solusi. Pentingnya pengembangan pembelajaran dilakukan yaitu untuk menjadikan pembelajaran lebih bermakna. Berbagai cara harus dilakukan untuk meningkatkan pembelajaran yang lebih bermakna, salah satunya adalah tanggap dalam menggunakan inovasi model pembelajaran yang dapat membuat siswa terlibat aktif dalam kegiatan belajar dengan secara bertahap dapat menanamkanketerampilan proses sains dan penguasaan konsep pada siswa sehingga pembelajaran bermakna bagi siswa. Dengan melibatkan suatu proses pembelajaran yang bermakna bagi siswa diyakini hal ini dapat meningkatkan ataupun membuat konsep-konsep materi yang disampaikan lebih mudah dipahami dan berkesan mendalam pada pikiran siswa (Hafizah, dkk., 2014).

Dalam pembelajaran sangat diperlukan inovasi guna membuat pembelajaran lebih menarik dan mengoptimalkan kegiatan belajar mengajar dengan tujuan menggiatkan aktivitas belajar siswa sehingga berdampak pada hasil belajar. Faktor yang memengaruhi pembelajaran yang lebih inovatif dan tentunya efektif adalah penggunaan media pembelajaran yang tepat, dalam artian dapat dilihat dan didengarkan. Dalam penelitian ini, teknologi digunakan sebagai media pembelajaran. Kemajuan teknologi di bidang pendidikan sangat membantu sebagai media pembelajaran. Media pembelajaran berbasis teknologi, seperti audiovisual mampu memvisualisasikan konsep abstrak yang tidak dapat ditampilkan pada peralatan nyata (Sukarno, 2014).

Fungsi media berbasis teknologi dalam pembelajaran adalah menyajikan dan mengklarifikasi materi yang hanya dapat ditemukan di luar kelas dan tersedia di dalam kelas. Penggunaan media berbasis teknologi dapat memudahkan dalam memperoleh pengetahuan yang tidak diperoleh karena keterbatasan ruang dan waktu atau alat percobaan dalam pembelajaran. Media berbasis teknologi juga digunakan untuk membuat penjelasan materi lebih luas dan meningkatkan proses pembelajaran yang berdampak pada pengetahuan konsep siswa (Kaniawati, Rusdiana, \& Kirana 2016). Dalam penelitian ini, teknologi yang digunakan sebagai media pembelajaran berupa media audiovisual.

Pembelajaran menggunakan media audiovisual mempunyai beberapa kelebihan. Kelebihan tersebut antara lain pembelajaran yang dilakukan lebih inovatif dan interaktif, mampu menggabungkan antara teks, gambar, dan musik yang saling mendukung, mampu memvisualisasikan materi yang abstrak menjadi konkret, menampilkan tampilan yang jelas, seperti melihat nyata dan hal-hal yang belum pernah diketahui siswa dapat dengan mudah diketahui. Selain itu, penggunaan media audiovisual dalam pembelajaran dapat memudahkan penjelasan materi yang tidak dilakukan melalui percobaan atau pengamatan secara langsung (Kaniawati, Rusdiana, \& Kirana 2016).

Penelitian ini model inkuiri terbimbing digunakan sebagai model pembelajaran. Model pembelajaran inkuiri yaitu pembelajaran berdasarkan penyelidikan dengan mengajak siswa melakukan proses ilmiah sebagai ilmuan mempelajari alam, memungkinkan siswa menggunakan semua kompetensinya untuk menemukan konsep itu sendiri (Nugraha, Kaniawati., Rusdiana, \& Kirana, 2016). Inkuiri bertujuan untuk melatih siswa memecahkan masalah. Dasar inkuiri yaitu siswa membangun pemahaman dengan mandiri melalui aktivitas penyelidikn pengetahuan (Sarwi, Sutardi, \& Prayitno, 2016).

Pembelajaran inkuiri terbimbing menempatkan siswa sebagai subjek yang dituntut berperan aktif saat proses pembelajaran. Siswa benar-benar memimpin proses penyelidikan sehingga memiliki gagasan yang baik mengenai hasil yang diharapkan dan dapat merumuskan kesimpulan secara mandiri (Sadeh \& Zion, 2009). Model pembelajaran inkuiri terbimbing mengajak siswa memahami konsep sains melalui metode ilmiah dengan tujuan pemahaman konsep tidak hanya informatif tetapi juga melibatkan aktivitas siswa dalam membangun pemahaman konsep (Asmawati, 2015).

Model inkuiri terbimbing sangat efektif diterapkan peda pembelajaran. Susilawati dan Sridana (2015) menyatakan inkuiri terbimbing dapat meningkattkan keterampiilan proses sains.Penelitian Setyawati, dkk. (2014) menyatakan proses belajar dengan berbasis inkuiri terbimbing secara efektif dapat meningkatkan kepahaman atau pemahaman siswa pada konsep yang diajarkan dan juga dapat meningkatkan rerata perolehan nilai keterampilan proses sains pada siswa. Sarwi, dkk. (2016) pada penelitiannya mengungkapkan bahwa inkuiri terbimbing secara signifikan berpengaruh pada variabel penguasaan konsep dan pengembangan karakter konservasi siswa.

Penggunaan media audiovisual pada model inkuiri terbimbing diharapkan meningkatkan taraf efektivitas dan tujuan pembelajaran dapat tercapai secara maksimal, disamping siswa melakukan percobaan secara ilmiah, siswa juga diberi pemahaman konsep melalui media audiovisual mengenai penjelasan materi, contoh atau peristiwa yang tidak memungkinkan untuk dilakukan dengan percobaan nyata. Implementasi media audiovisual pada model inkuiri terbimbing mengajarkan siswa lebih percaya pada kemampuan sendiri dalam berpikir, mencari informasi dan belajar dari sumber lain. (Maduretno, dkk., 2017).

Media audiovisual digunakan pada model inkuiri terbimbing karena menyesuaikan karakter materi yang memerlukan penjelasan lebih konkret untuk membantu siswa memahami konsep yang disampaikan dan pembelajaran menjadi lebih menarik sehingga menumbuhkan minat siswa untuk melaksanakan aktivitas belajar. Pembelajaran dengan memanfaatkan video sebagai media pembelajaran mampu memberikan dampak positif, seperti meningkatkan pemahaman dan penguasaan konsep siswa (Nugraha, Kaniawati, Rusdiana, \& Kirana, 2016).

Berdasarkan ulasan mendalam pada latar belakang, untuk dapat meningkatkan penguasaan konsep siswa khususnya pada pelajaran IPA, peneliti melakukan penelitian di SDN Tanjungrejo 2 Malang menggunakan strategi model pembelajaran yang sesuai. Dengan demikian, maka dilakukan penelitian terhadap siswa kelas IV pada pembelajaran IPA tentang sifat-sifat bunyi dan keterkaitannya dengan indera pendengaran. 


\section{METODE}

Jenis penelitian adalah quassy experimental design. Penelitian ini menggunakan dua kelompok yang terdiri dari satu kelompok eksperimen dan satu kelompok kontrol. Sesuai dengan ketentuan yang ada, kelompok eksperimen diberikan perlakuan dengan penggunaan media audiovisual dalam model inkuiri terbimbing, sedangkan kelompok kontrol belajar menggunakan model inkuiri terbimbing. Penelitian ini menggunakan desain kelompok kontrol pretest-postest.

Tabel 1. Pretest-Posttest Control Group Design

\begin{tabular}{lccccc}
\hline Kelompok & \multicolumn{2}{c}{ Pretes } & Perlakuan & \multicolumn{2}{c}{ Postes } \\
\hline \multirow{2}{*}{ Kksperimen } & PK & & KPS & PK \\
\cline { 2 - 6 } Kontrol & $\mathrm{O}_{1}$ & $\mathrm{O}_{3}$ & $\mathrm{X}$ & $\mathrm{O}_{2}$ & $\mathrm{O}_{4}$ \\
& $\mathrm{O}_{5}$ & $\mathrm{O}_{7}$ & - & $\mathrm{O}_{6}$ & $\mathrm{O}_{8}$ \\
\hline
\end{tabular}

Keterangan:

$\mathrm{O}_{1}, \mathrm{O}_{2}, \mathrm{O}_{5}, \mathrm{O}_{6} \quad$ : tes keterampilan proses sains

$\mathrm{O}_{3} \mathrm{O}_{4} \mathrm{O}_{7} \mathrm{O}_{8} \quad$ : penguasaan konsep

$\mathrm{X} \quad$ : pembelajaran dengan media audiovisual pada inkuiri terbimbing

Subjek yang digunakan adalah seluruh anak kelas IV SDN Tanjungrejo 2 Malang tahun ajaran 2018/2019 sebanyak 84 orang. Penentuan sampel dilakukan dengan acak dan diperoleh 43 anak sebagai kelas eksperimen dan 41 anak kelas kontrol. Penentuan sempel dengan teknik simple random sampliing. Peneliti mengacak kelas yang akan dijadikan sampel dengan cara mengundi kelas yang akan dipilih sebagai sampel penelitian.

Variabel bebas yang digunakan adalah media audiovisual pada model inkuiri terbimbing. Variabel terikat dalam penelitian ini adalah Keterampilan Proses Sains dan penguasaan konsep IPA. Pengujian kedua variabel akan dilakukan uji hipotesis sebagai berikut:

$\mathrm{H}_{0}$ : Tidak ada pengaruh yang signifikan pada penggunaan media audiovisual pada inkuiri terbimbing terhadap Keterampilan

Proses Sains dan penguasaan konsep IPA siswa kelas IV SDN Tanjungrejo 2 Malang.

$\mathrm{H}_{1}$ : Ada pengaruh yang signifikan pada penggunaan media audiovisual pada model inkuiri terbimbing terhadap Keterampilan

Proses Sains dan penguasaan konsep IPA siswa kelas IV SDN Tanjungrejo 2 Malang.

Instrumen yang digunakan pada pengambilan data adalah lembar observasi dan tes. Tes digunakan untuk mengukur Ketarampilan Proses Sains dan penguasaan konsep IPA. Tes Keterampilan Proses Sains yang diukur adalah aspek mengamati, memprediksi, menggolongkan, mengukur, membuat tabel, membuat grafik, menyimpulkan, dan mengomunikasikan. Aspek mengamati dan mengomunikasikan diukur dengan observasi terhadap siswa saat proses pembelajaran berlangsung dan keenam aspek lainnya diukur menggunakan tes berbentuk esai. Tes untuk mengukur penguasaan konsep IPA berbentuk pilihan ganda pada batas ranah kognitif C4 (analisis). Instrumen yang digunakan dilakukan uji validitas soal, daya beda, tingkat kesukaran butir soal, dan reliabilitas terlebih dahulu. Keempat uji tersebut dilakukan dengan mengguanakan SPSS.

Analisis mengggunakan analisis statistik parametrik dengan menggunakan uji analisis kovarian (ANAKOVA) berbantuan SPSS dengan nilai pretes sebagai kovariatnya. Pengujian hipotesis dilakukan untuk mengetahui perbandingan hasil Keterampilan Proses Sains dan penguasaan konsep IPA kedua sampel penelitian. Sebelum pengujian hipotesis, data pretest dan posttet diuji melalui uji prasyarat yang meliputi uji kenormalan dan kehomogenan. Uji kenormalan dan uji homogenitas menggunakann SPSS 22.

\section{HASIL}

Fokus data adalah hasil nilai tes dan non-tes dari Keterampilan Proses Sains dan penguasaan konsep. Nilai tes pretest dan posttest Keterampilan Proses Sains siswa kelas eksperimen dan kelas kontrol dapat dilihat pada Tabel 2 dan nilai rata-rata observasi Keterampilan Proses Sains indikator mengamati dan mengomunikasikan dapat dilihat pada Tabel 3.

Tabel 2. Data Pretest dan Posttest Keterampilan Proses Sains

\begin{tabular}{llccccc}
\hline JenisTes & \multicolumn{1}{c}{ Kelas } & N & Rata-rata & Standar Deviasi & Minimum & Maksimum \\
\hline Pre-tes & Eksperimen & 43 & 68,99 & 12,41 & 44,44 & 88,89 \\
& Kontrol & 41 & 65,56 & 12,52 & 55,56 & 88,89 \\
Pos-tes & Eksperimen & 43 & 83,46 & 10,61 & 66,67 & 100,00 \\
& Kontrol & 41 & 78,06 & 9,44 & 66,67 & 100,00 \\
\hline
\end{tabular}

Berdasarkan tabel di atas diperoleh nilai rata-rata Keterampilan Proses Sains di kelas eksperimen dengan penggunaan media audiovisual pada model inkuiri terbimbing lebih tinggi dibandingkan di kelas kontrol siswa belajar dengan model inkuiri terbimbing. Nilai posttest Keterampilan Proses Sains kelas eksperimen memiliki rata-rata 83,46, sedangkan kelas kontrol dengan nilai 78,06. Selanjutnya, nilai Keterampilan Proses Sains dengan instrumen non tes berupa lembar observasi guru 
terhadap aktivitas siswa yaitu kegiatan pengamatan siswa terhadap bahan/alat yang digunakan saat melakukan percobaan dan aktivitas siswa dalam mengomunikasikan ide saat peroses belajar berlangsung. Gambaran pencapaian nilai rata-rata aktivitas Keterampilan Proses Sains siswa indikator mengamati dan mengomunikasikan saat proses pembelajaran berlangsung dapat dilihat pada Tabel 3 .

Tabel 3. Data Aktivitas Keterampilan Proses Sains pada Indikator Mengamati dan Mengomunikasikan

\begin{tabular}{clccccc}
\hline Jenis Tes & Kelas & N & Rata-rata & Standar Deviasi & Minimum & Maksimum \\
\hline Pengamatan Selama Proses & Eksperimen & 43 & 83,72 & 18,36 & 16,67 & 100,00 \\
& Kontrol & 41 & 73,76 & 19,22 & 33,33 & 100,00 \\
\hline
\end{tabular}

Berdasarkan hasil diatas tampak bahwa nilai rata-rata aktivitas Keterampilan Proses Sains siswa pada indikator mengamati dan mengomunikasikan di kelas eksperimen 83,72, sedangkan di kelas kontrol mendapat nilai 73,76. Hal ini menunjukkan bahwa observasi terhadap Keterampilan Proses Sains siswa di kelas eksperimen dengan penggunaan media audiovisual pada model inkuiri terbimbing mendapat nilai rata-rata lebih tinggi dibandingkan dengan kelas kontrol yang belajar dengan inkuiri terbimbing. Penelitian ini mengukur delapan indikator keterampilan proses pada saat proses pembelajaran berlangsung. Data hasil pencapaian nilai rata-rata keterampilan proses sains setiap indikator pada pembelajaran dapat dilihat pada Gambar 1 dan 2.

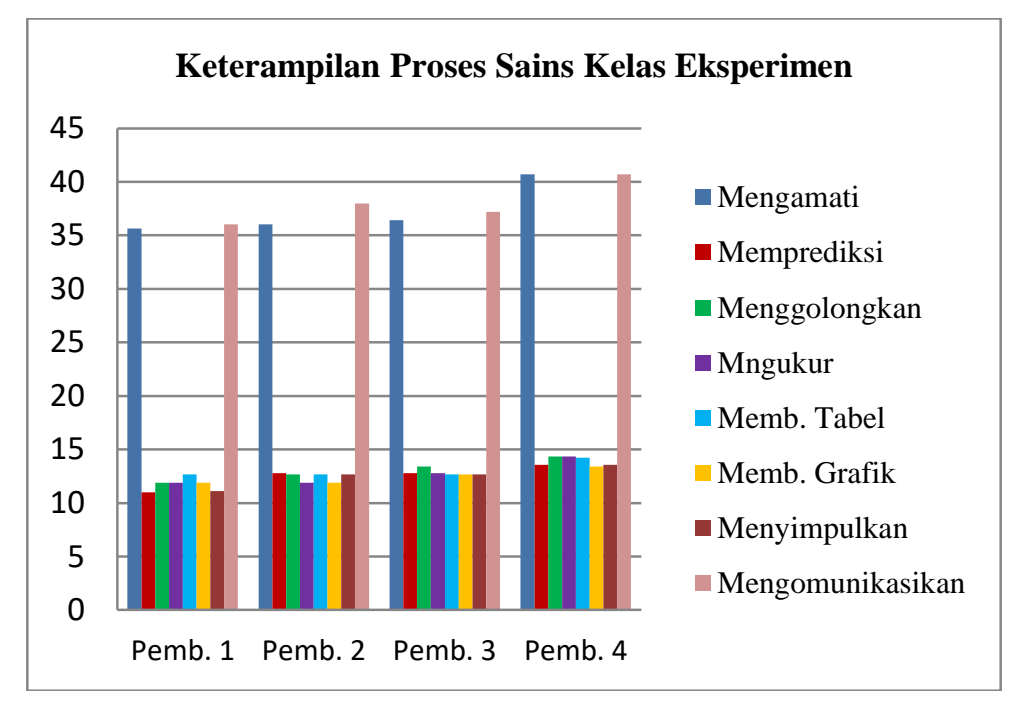

Gambar 1. Grafik Nilai Rata-rata Indikator Keterampilan Proses Sains Kelas Eksperimen

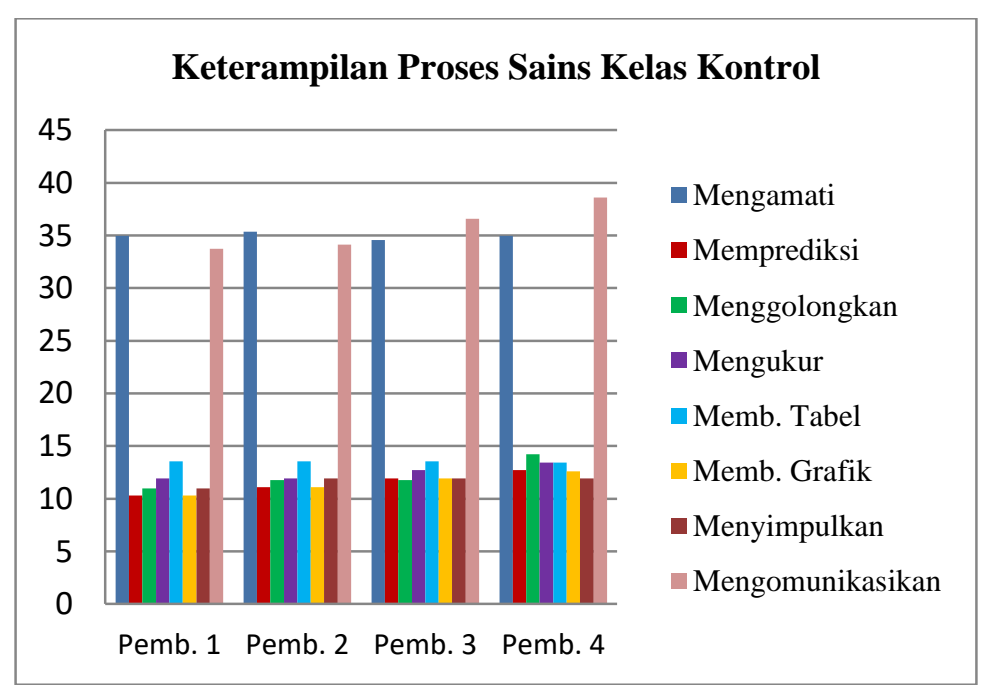

Gambar 2. Grafik Nilai Rata-rata Indikator Keterampilan Proses Sains Kelas Kontrol 
Berdasarkan hasil di atas, tampak bahwa kelas eksperimen yang belajar dengan penggunaan media audiovisual pada model inkuiri terbimbing lebih unggul dibandingkan kelas kontrol dengan model inkuiri pada setiap indikator keterampilan proses sains. Jika dilihat pada setiap kali pertemuan, semua indikator keterampilan proses sains meningkat secara stabil dan lebih signifikan pada kelompok eksperimen dengan media audiovisual pada inkuiri terbimbing daripada kelompok kontrol dengan inkuiri terbimbing saja.

Pada pertemuan ke-4 nilai rata-rata setiap indikator Keterampilan Proses Sains saat proses pembelajaran berlangsung lebih tinggi di kelas eksperimen, dilihat pada indikator mengamati dengan nilai rata-rata 40,69, indikator memprediksi 13,56, indikator menggolongkan 14,34, indikator mengukur 14,34, indikator membuat tabel 14,21, indikator membuat grafik 13,43, indikator menyimpulkan 13,56, dan indikator mengomunikasikan 40,69 dibandingkan dengan rata-rata setiap indikator Keterampilan Proses Sains di kelas kontrol pada pertemuan keempat indikator mengamati dengan nilai rata-rata 34,95, indikator memprediksi 12,73, indikator menggolongkan 14,22, indikator mengukur 13,41, indikator membuat tabel 13,41, indikator membuat grafik 12,6, indikator menyimpulkan 11,92, dan indikator mengomunikasikan 38,61.

Selanjutnya, data hasil penguasaan konsep yang akan diukur dengan menggunakan tes dengan uji perbedaan kelas pada kelas eksperimen dengan kontrol. Soal-soal yang dikembangkan merupakan soal pilihan ganda yang telah dilakukan uji empiris untuk mengetahui nilai validitas dan reliabilitasnya. Data hasil penguasaan konsep diukur menggunakan instrumen tes berupa pilihan ganda materi sifat-sifat bunyi dan keterkaitannya dengan indera pendengaran. Instrumen terdiri dari 16 soal pilihan ganda yang telah divalidasi, kemudian digunakan untuk pretest dan posttest penguasaan konsep IPA. Nilai penguasaan konsep IPA dapat dilihat pada Tabel 4.

Tabel 4. Data Pretest dan Posttest Penguasaan Konsep IPA

\begin{tabular}{llccccc}
\hline Jenis Tes & \multicolumn{1}{c}{ Kelas } & N & Rata-rata & Standar Deviasi & Minimum & Maksimum \\
\hline Pre-tes & Eksperimen & 43 & 68,91 & 10,42 & 43,8 & 87,5 \\
& Kontrol & 41 & 67,85 & 9,34 & 50 & 87,8 \\
\multirow{2}{*}{ Pos-tes } & & & & & 68,8 & 100,00 \\
& Eksperimen & 43 & 86,95 & 8,60 & 62,5 & 100,00 \\
\hline
\end{tabular}

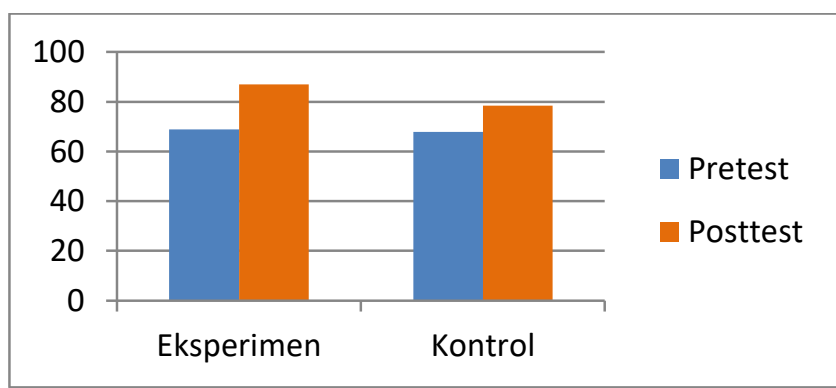

Gambar 3. Grafik Nilai Rata-rata Penguasaan Konsep Siswa Kelas Eksperimen dan Kelas Kontrol

Dari data yang diperoleh terlihat bahwa nilai rata-rata penguasaan konsep IPA yang dimiliki siswa pada kelas eksperimen dengan penggunaan media audiovisual pada model inkuiri terbimbing diketahui lebih tinggi dibandingkan kelas kontrol hanya denganinkuiri terbimbing saja. Nilai posttest penguasaan konsep IPA kelas eksperimen memiliki rata-rata 86,95 dan kelas kontrol 78,44. Dapat disimpulkan bahwa peningkatan rata-rata nilai tes penguasaan konsep IPA menginterpretasikan keberhasilan penggunaan media audiovisual pada model inkuiri terbimbing memberikan pengaruh terhadap penguasaan konsep IPA siswa.

Nilai pretest dan posttestakan dilakukan uji hipotesis. Sebelum dilakukan uji hipotesis, dilakukan uji prasayarat normalitas dan homgentas data untuk mengetahui jenis statistik yang digunakan. Pada uji normalitas yang digunakan untuk mengetahui normal tidaknya data digunakan uji Kolmogorov-Smirnov. Hasil uji ini menunjukkan bahwa taraf nilai signifikansi $>$ 0,05, maka data terdistribusi normal. Hasil uji normalitas data pretest dan posttest dapat dilihat pada Tabel 5 dan 6.

Tabel 5. Hasil Uji Normalitas Keterampilan Proses Sains

\begin{tabular}{llcc}
\hline \multicolumn{2}{c}{ Keterampilan Proses Sains } & \multicolumn{2}{c}{ Kolmogorov-Sminornov $^{\mathbf{a}}$} \\
\hline \multirow{3}{*}{ Pretest } & $\mathrm{df}$ & Sig. \\
& & 43 & 1,882 \\
\multirow{3}{*}{ Posttest } & Kelas Eksperimen & 41 & 2,195 \\
& Kelas Kontrol & 41 & 1,801 \\
& Kelas Eksperimen & 43 & 1,152 \\
\hline
\end{tabular}


Tabel 6. Hasil Uji Normalitas Penguasaan Konsep IPA

\begin{tabular}{llcc}
\hline \multicolumn{2}{c}{ Penguasaan Konsep } & \multicolumn{2}{c}{ Kolmogorov-Sminornov $^{\mathbf{a}}$} \\
\hline \multirow{4}{*}{ Pretest } & $\mathrm{df}$ & Sig. \\
\multirow{4}{*}{ Posttest } & Kelas Eksperimen & 43 & 1,214 \\
& Kelas Kontrol & 41 & 1,397 \\
& Kelas Eksperimen & 43 & 1,840 \\
& Kelas Kontrol & 41 & 1,107 \\
\hline
\end{tabular}

Dari data hasil pengujian normalitas Keterampilan Proses Sains dan penguasaan konsep diketahui data pretes dan postes di kedua kelas menghasilkan nilai uji signifikansi > 0,05. Disimpulkan data Keterampilan Proses Sains dan penguasaan konsep kelas eksperimen dan kontrol terdistribusi norrmal. Selanjutnya dilakukan uji homogenitas untuk mengetahui homogenitas data dengan menggunakan Levene Statistic. Hasil uji homogenitas menunjukkan nilai taraf signifikansi yang diperoleh > 0,05. Jika kedua data pada setiap kelas memiliki hasil signifikansi pretest-posttest yang diiperoleh > 0,05 berarti data Keterampilan Proses Sains dan penguasaan konsep IPA siswa homogen.

Tabel 7. Uji Homogenitas Pretest-Posttest Keterampilan Proses Sains

\begin{tabular}{lcccc}
\hline Kelompok & Levene Statistic & df1 & df2 & Sig. \\
\hline Eksperimen &, 109 & 1 & 84 &, 743 \\
Kontrol & 3,846 & 1 & 80 &, 053 \\
\hline
\end{tabular}

Tabel 8. Uji Homogenitas Pretest-Posttest Penguasaan Konsep IPA

\begin{tabular}{lcccc}
\hline & Levene Statistic & df1 & df2 & Sig. \\
\hline Kelas Eksperimen &, 865 & 1 & 84 &, 355 \\
Kelas Kontrol &, 168 & 1 & 80 &, 683 \\
\hline
\end{tabular}

Hasil pengujian homogenitas dua sampel pada Tabel 7 dan 8, menyatakan hasil signifikansi pretest dan postest yang diperoleh > 0,05. Kesimpulannya adalah data Keterampilan Proses Sains dan penguasaan konsep IPA siswa nilai pretes dan postes pada kelas eksperimen dan kontrol adalah homogen.

Hasil uji prasyarat membuktikan distribusi data normal dan homogen, maka statistik yang digunakan untuk uji hipotesis adalah statistic parametric. Uji hipotesis dilakukan dengan membandingkan kelompok yang berbeda perlakuan dengan menggunakan analisis kovariat (ANAKOVA) dengan bantuan SPSS 22 dengan nilai pretes sebagai kovariatnya. Ringkasan hasiil uji hipotesis sebgai berikut.

Tabel 9. Hasil Uji Hipotesis Keterampilan Proses Sains dengan Anakova

\begin{tabular}{lcccc}
\hline & & & \multicolumn{2}{c}{ 95\% Confidence Interval } \\
\hline Kelas & Mean & Std. Error & Lower Bound & Upper Bound \\
Kontrol & $78,309^{\mathrm{a}}$ & 1,600 & 75,125 & 81,492 \\
Eksperimen & $83,474^{\mathrm{a}}$ & 1,562 & 80,366 & 86,581
\end{tabular}

a. Covariates appearing in the model are evaluated at the following values: Pretes KPS =67,2629.

Hasil perhitungan statistik menunjukkan bahwa kelas yang dibelajarkan dengan penggunan media audiovisual pada model inkuiri terbimbing mempunyai nilai Keterampilan Proses Sains lebih tinggi $\left(\right.$ Mean $\left.=83,474 ; S_{E}=1,562\right)$, dibandingkan dengan kelas kontrol yang menggunakan pembelajaran inkuiri terbimbing (Mean $=78,309 ; \mathrm{S}_{\mathrm{E}}=1,600$ ). Dari hasil uji Anakova disimpulkan terdapat pengaruh signifikan penggunaan media audiovisual pada model inkuiriterbimbing terhadap Keterampilan Proses Sains $<0,05(0,000<0,05)$.

Tabel 10. Hasil Uji Hipotesis Penguasaan Konsep IPA dengan Anakova

\begin{tabular}{|c|c|c|c|c|}
\hline & & \multicolumn{3}{|c|}{ 95\% Confidence Interval } \\
\hline Kelas & Mean & Std. Error & Lower Bound & Upper Bound \\
\hline Eksperimen & $86,734^{a}$ & 1,214 & 84,317 & 89,150 \\
\hline Kontrol & $78,463^{\mathrm{a}}$ & 1,186 & 76,104 & 80,822 \\
\hline
\end{tabular}


Hasil perhitungan statistik menunjukkan kelas eksperimen dengan menggunakan media audiovisual mempunyai nilai rata-rata penguasaan konsep IPA yang lebih tinggi (Mean $=86,734 ; \mathrm{S}_{\mathrm{E}}=1,214$ ), dibandingkan dengan kelas kontrol yang menggunakan pembelajaran inkuiri terbimbing (Mean $=78,463 ; \mathrm{S}_{\mathrm{E}}=1,186$.). Dari hasil uji hipotesis yang dilakukan dengan Anakova secara statistik disimpulkan ada perbedaan yang signifikan pada penggunaan media audiovisual pada model inkuiri terbimbing terhadap penguasaan konsep IPA $<0,05(0,000<0,05)$.

\section{PEMBAHASAN}

Penelitian ini menggunakan kovariat pretes. Nilai kovariat atau pretes pada setiap kelas dihasilkan bahwa kedua kelas cenderung memiliki kemampuan awal yang hampir sama. Perbedaan rerata kedua kelas tidak jauh berbeda. Setelah pretest dilakukan pada masing-masing kelompok kelas, kedua kelas diberikan perlakuan yang berbeda. Kelas IV A sebagai kelas eksperimen dengan penggunaan media audiovisual pada modelinkuiri terbimbing, sedangkan kelas IV B sebagai kelas kontrol dengan model inkuiri terbimbing saja. Selanjutnya, dilaksanakan posttest pada setiap kelompok kelas dengan instrumen tes yang sama.

Hasil uji hipotesis menunjukkan bahwa nilai rata-rata Keterampilan Proses Sains dan penguasaan konsep IPA siswa kelas eksperimen lebih tinggi dibandingkan kelas kontrol. Kelas eksperimen yang dibelajarkan dengan penggunaan media audiovisual pada model inkuiri terbimbing mempunyai nilai Keterampilan Proses Sains lebih tinggi (Mean = 83,474; $\mathrm{S}_{\mathrm{E}}=$ 1,562), dibandingkan dengan kelas kontrol menggunakan model pembelajaran inkuiri terbimbing saja (Mean $=78,309 ; \mathrm{S}_{\mathrm{E}}=$ 1,600), begitu juga dengan nilai penguasaan konsep IPA kelas eksperimen lebih tinggi jika dikomparasikan dengan kelas kontrol (Mean $=86,734 ; \mathrm{S}_{\mathrm{E}}=1,214$ ) dibandingkan dengan kelas kontrol (Mean $=78,463 ; \mathrm{S}_{\mathrm{E}}=1,186$ ). Kesimpulan hasil uji hipotesis ada pebedaan hasil dan pengaruh yang signifikan terhadap Keterampilan Proses Sains dan penguasaan konsep IPA kelas eksperimen yang menggunakan media audiovisual pada model inkuiri terbimbing dibandingkan kelas kontrol menggunakan model inkuiri terbimbing pada siswa kelas IV SDN Tanjungrejo 2 Malang.

Sejalan dengan kesimpulan penelitian terdahulu, hasil penelitian ini terkait dengan penggunaan media audiovisual dan model inkuiri terbimbing dalam pembelajaran dapat meningkatkan Keterampilan Proses Sains dan penguasaan konsep siswa seperti (1) Kaniawati, Samsudin, Hasopa, Sutrisno, \& Suhendi (2016) menyatakan ada pengaruh yang signifikan pada penguasaan konsep siswa yang belajar menggunakan media audiovisual dibuktikan dengan skor rata-rata postes yang lebih tinggidari skor pretes; (2) Nugraha, Kaniawati, Rusdiana, \& Kirana (2016) tentang pengaruh pembelajaran dengan pemanfaatan media video terhadap penguasaan konsep siswa dengan hasil temuan bahwa ada perbedaan yang signifikan dalam mean score siswa yang diajarkan menggunakan video dengan siswa yang dibelajarkan tanpa menggunakan media video; (3) Aktamis, dkk. (2016) mendapati temuan bahwa pembelajaran berbasis inkuiri memiliki pengaruh pada Keterampilan Proses Sains, sikap siswa terhadap sains dan prestasi siswa. Hal ini menunjukkan bahwa penelitain yang dilakukaan saat ini berhasil untuk meningkatkan ketrampilan proses sains; (4) Sarwi, Sutardi, \& Prayitno (2016) mendapati pembelajaran dengan inkuiri terbimbing secara signifikan berpengaruh pada peningkatan penguasaan konsep dan pengembangan terhadap karakter konservasi yang dimiliki siswa. Hal ini menunjukkan penguasaan konsep sesuai dengan penggunaan model inkuiri; (5) Susilawati dan Sridana (2015) menyatakan pembelajaran dengan inkuiri terbimbing dapat meningkatkan Keterampilan Proses Sains siswa.

Hasil pembahasan pada penelitian eksperimen ini menjelaskan dan membuktikan bahwa penggunaan media audiovisual pada model pembelajaran inkuiri terbimbing memberikan konstribusi positif. Selain positif, hasil penelitian juga memberikan nilai efektif terhadap Keterampilan Proses Sains dan penguasaan konsep IPA pada kelas IV SDN Tanjungrejo 2 Malang. Penggunaan media audiovisual pada model inkuiri terbimbing memiliki hasil Keterampilan Proses Sains dan penguasaan konsep IPA siswa lebih tinggi dengan pembanding adalah kelas kontrol yang hanya menggunakan model pembelajaran inkuiri terbimbing. Pada penelitian ini menunjukkan bahwa penggunaan media audiovisual pada model pembelajaran inkuiri terbimbing sangat efektif digunakan.

\section{SIMPULAN}

Berdasarkan hasil kajian dan analisis data yang dilakukan, diperoleh simpulan sebagai berikut. Pertama, ada perbedaan hasil Keterampilan Proses Sains dan penguasaan konsep IPA kelas yang menggunakan media audiovisual pada model inkuiri terbimbing dan kelompok belajar yang hanya menggunakan pembelajaran inkuiri terbimbing saja. Kedua, signifikansi pada penggunaan media audiovisual pada model pembelajaran inkuiri terbimbing terhadap Keterampilan Proses Sains dan penguasaan konsep siswa kelas IV SDN Tanjungrejo 2 Malang memiliki pengaruh yang besar. Nilai rata-rata Keterampilan Proses Sains dan penguasaan konsep siswa kelas eksperimen dengan menggunakan media audiovisual pada model inkuiri terbimbing lebih tinggi dibandingkan dengan siswa kelas kontrol yang belajar dengan model pembelajarann inkuiri terbimbing.

Saran perbaikan kedepannya perlu dilakukan perencanaan lebih baik. Perencanaan yang baik dengan harapan hasil yang diperoleh lebih maksimal dan efisien. Dalam penggunaan media audiovisual terlebih dahulu guru benar-benar memilah video yang cocok dengan materi dan karakteristik siswa dan kontrol guru harus ada di setiap tahapan pembelajaran. 


\section{DAFTAR RUJUKAN}

Aktamis, H., Higde, E., \& Ozden, B. (2016). Effects of the Inquiry-Based Learning Method on Students'Achievement, Science Process Skills and Attitudes Towards Science: A Meta-Analysis Science. Journal of Turkish Science Education, 13 (4), $248-261$.

Asmawati, E. Y. (2015). Lembar Kerja Siswa menggunakan Model Guided Inquiry untuk Meningkatkan Keterampilan Berpikir Kritis dan Penguasaan Konsep Siswa. Jurnal Pendidikan Fisika, 3(1). https://doi.org/10.24127/jpf.v3i1.13

Creswell, J. W. (2012). Research Design Pendekatan Kualitatif, Kuantitatif, dan Mixed. Cetakan ke-2, Yogyakarta: Pustaka Pelajar.

Depdiknas. (2007). Peraturan Menteri Pendidikan Nasional No 20 Tahun 2007 tentang Standar Penilaian.

Dewi, N. L., Dantes, N., \& Sadia, I. W. (2013). Pengaruh Model Pembelajaran Inkuiri Terbimbing terhadap Sikap Ilmiah dan Hasil Belajar IPA. PENDASI: Jurnal Pendidikan Dasar Indonesia, 3(1).

Hafizah, E., Hidayat, A., \& Muhardjito. (2014). Pengaruh Model Pembelajaran Anchored Instruction terhadap Penguasaan Konsep dan Kemampuan Pemecahan Masalah Fisika Siswa Kelas X. Jurnal Fisika Indonesia, 18(52), 8-12.

Kaniawati, I., Samsudin, A., Hasopa, Y., Sutrisno, A. D., \& Suhendi, E. (2016). The Influence of Using Momentum and Impulse Computer Simulation to Senior High School Students' Concept Mastery. Journal of Physics: Conference Series, $739(1), 12060$.

Maduretno, T.W., Tantowi A. A., \& Luluk, F. (2017). The Effect of Video-Assisted Inquiry Modified Learning Model on Student's Achievement on ${ }^{1}$ stFundamental Physics Practice. International Journal of $S$ cience and Applied Science: Conference Series, 2(1), 403-412. DOI: 10.20961/ijsascs.v2i1.16756

Nugraha, M. G., Kaniawati, I., Rusdiana, D., \& Kirana, K. H. (2016). Combination of Inquiry Learning Model and Computer Simulation to Improve Mastery Concept and The Correlation with Critical Thinking Skills. In AIP Conference Proceedings (Vol. 1708).

Sadeh, I., \& Zion, M. (2009). The Development of Dynamic Inquiry Performances Within an Open Inquiry Setting: A Comparison to Guided Inquiry Setting. Journal of Research in Science Teaching, 46(10), 1137-1160.

Sarwi., Sutardi., \& Prayitno, W. W. (2016). Implementation of Guided Inquiry Physics Instruction to Increase an Understanding Concept and to Develop the Students' Character Conservation. Jurnal Pendidikan Fisika Indonesia, 12(1), 33-40.

Setyawati, N. W. I., Candiasa, I. M., \& Yudana, I. M. (2014). Pengaruh Model Pembelajaran Inkuiri Terbimbing terhadap Pemahaman Konsep dan Keterampilan Proses Sains Siswa Kelas XI IPA SMA Negeri 2 Kuta Kabupaten Badung. Jurnal Administrasi Pendidikan, 5(1).

Supriyatman., \& Sukarno. (2014). Improving Science Process Skills Science Concepts Mastery Prospective Student Teachers Through Inquiry Learning Instruction Model by Using Interactive Computer Simulation. International Journal of Science and Research (IJSR), 3(2), 6-9

Susilawati, \& Sridana, N. (2015). Pengaruh Model Pembelajaran Inkuiri Terbimbing terhadap Keterampilan Proses Sains Siswa. Jurnal Tadris IPA Biologi FITK IAIN Mataram, 8(1), 27-36. 